\title{
Komunikasi Kesehatan: Penyebaran Informasi Gaya Hidup Sehat
}

\begin{abstract}
Anne Ratnasari
ABSTRACT

This paper is concerned with the dissemination of Healthy Lifestyle information. Healthy Lifestyle which applying food combining approach recently is hailed as a breakthrough in health communication. Meanwhile, the dissemination process consists of message characteristic, communication channel, and range of time period. The innovation on message characteristic involves factors such as relative benefit, compatibility, and complexity. Relative innovation is generated from economy aspect: by applying healthy lifestyle information, it is strongly hoped that human body will become healthy, full of energy, and free from disease. On the other hand, there is difficulty on compatibility factors, due to society's eating pattern which referred on four-healthy pattern for every meal, not for a whole day. The spread of information need a deep toward lifestyle - add complexity for the matter.

The communication channels to widespread this information to the public utilize a combination of interpersonal communication (for consultation), group communication (public speech), and mass communication (print media). Time is also a crucial factor in planning information dissemination.
\end{abstract}

Kata kunci: diseminasi, informasi, komunikasi kesehatan, gaya hidup sehat

\section{Pendahuluan}

Dalam kehidupan modern saat ini, banyak cara ditempuh individu untuk menjaga kesehatan tubuh. Sesuai saran ahli gizi, berbagai macam menu makanan diolah, disajikan, dan dikonsumsi untuk mencapai kesehatan optimal.

Seiring dengan tumbuhnya kesadaran akan pemeliharaan kesehatan, variasi kuliner mudah dijumpai, baik yang disajikan tayangan televisi, maupun dimuat di media cetak. Semuanya terlihat begitu menggugah selera, dan lezat. Dari menu tradisional, modern, bahkan sajian kreatif yang membuat orang sering tergoda untuk menikmatinya. Hal itu tidak salah selama orang dapat mengontrol asupan makanannya. Apabila terjadi sebaliknya, di mana orang makan melebihi kebutuhan tubuhnya, menurut hasil penelitian, "berisiko pada timbulnya penyakit, seperti jantung koroner, diabetis mellitus, hipertensi, arthritis, batu empedu, dan penyakit lainnya" (Wirakusumah, 1997:29-32).

Keadaan ini mendapat perhatian yang cukup serius dari para ahli nutrisi, di antaranya, menginformasikan kepada individu atau masyarakat agar disiplin memilih makanan yang harus dikonsumsi dan hindari. Karena pola makan 
sehari-hari akan memengaruhi kesehatan mereka.

Terdapat berbagai macam pola makan yang dikenalkan ahli gizi dan dianut masyarakat, sebagai salah satu bentuk dari gaya hidup sehat. Gaya hidup sehat pada intinya "mengerjakan secara konsisten pola makan sehat dan berolah raga dengan cukup". ${ }^{1}$ Pola makan sehat adalah makanan yang seimbang dan sesuai dengan kebutuhan masing-masing. Bagi individu yang lebih banyak bekerja di belakang meja, misalnya, "kemungkinan hanya membutuhkan makanan yang mengandung 1.700 - 1.900 kalori, dan untuk memenuhi kebutuhan ini, makanan yang dikonsumsi di antaranya mengandung karbohidrat, protein, lemak, serat, vitamin, dan mineral."’2

Untuk pola makan, beberapa program atau pedoman yang diperkenalkan ahli nutrisi mungkin berbeda prinsip dan tujuannya. Salah satunya, kombinasi makanan serasi yang dikenal food combining, yaitu "pola makan yang diselaraskan dengan mekanisme alamiah fungsi tubuh manusia. Tujuannya, untuk memudahkan kerja pencernaan dan pemanfaatan energi sehingga lebih efisien" (Gunawan, 2001:34).

Food combining, sejak pertama kali, dipopulerkan oleh seorang ahli bedah dari Amerika Serikat, dr. William Howard Hay, sampai sekarang masih dianggap kontroversial. Pola makan ini mendapat kritikan dan dukungan dari para pengikutnya. Mereka yang mengeritik, antara lain, berpendapat pola makan ini dianggap tidak ilmiah, dan dapat membuat orang kekurangan gizi. Sedangkan yang mendukung menyambut hangat pola makan ini. Sebagai contoh, seperti dilaporkan majalah Nirmala (2002), "tanggapan dalam seminar food combining, banyak peserta datang untuk berkonsultasi, bahkan permintaan untuk memberikan ceramah food combining makin meluas."

Memerhatikan manfaatnya, menerapkan kombinasi makanan serasi dalam kehidupan seharihari merupakan salah satu solusi memeroleh kesehatan optimal. Mencapai kesehatan optimal menjadi salah satu aspek yang dituju komunikasi kesehatan seperti diungkapkan Piotrow (1997), ${ }^{4}$ Jackson \& Duffy (1998), "komunikasi kesehatan meliputi kajian bidang komunikasi dan kesehatan. Di mana kajian ini memokuskan pada penggunaan strategi komunikasi yang menginformasikan dan memengaruhi keputusan individu dan masyarakat dalam mempertinggi kesehatan. Kenaikan tersebut diakui sebagai elemen penting dari usaha untuk memperbaiki kesehatan perseorangan maupun masyarakat."

Menelaah informasi gaya hidup sehat dengan menerapkan food combining merupakan sebuah upaya yang memerlukan perhatian khusus. Sebab, muatan yang terkandung di dalamnya berhubungan dengan sesuatu yang baru, dan belum diketahui bagaimana tingkat penerimaaan individu atau masyarakat terhadap informasi tersebut. Karena itu, di benak penulis terlintas pertanyaaan: apakah informasi tersebut akan diserap masyarakat luas? Apakah terdapat kendala yang mungkin dihadapi dalam penyebarannya?

Tulisan ini membahas tinjauan teoretis penyebaran informasi gaya hidup sehat dari sudut pandang teori difusi inovasi. Menurut Rogers, yang dikutip Stephen D. Perry (dalam Baldwin, et al., 2004:221), teori ini memusatkan perhatian pada "penyebaran pengetahuan baru dan produk baru dalam masyarakat melalui media massa, antara lain, mencakup inovasi, saluran komunikasi, dan rentang waktu."

Berdasarkan pendapat Rogers tersebut, pembahasan tulisan ini difokuskan pada karakteristik pesan, saluran komunikasi, dan rentang waktu penyebaran gagasan gaya hidup sehat dengan menerapkan food combining sebagai inovasi baru di bidang kesehatan kepada masyarakat.

\section{Teori Difusi Inovasi}

Sebelum menjelaskan teori difusi inovasi, terlebih dahulu penulis uraikan aspek-aspek yang berhubungan dengan perubahan sosial dan komunikasi. Menurut Soekamto (1982:58), "perubahan sosial terjadi karena adanya interaksi sosial, sebagai bentuk utama dari proses-proses sosial. Sedangkan interaksi sosial terjadi apabila adanya kontak sosial dan komunikasi.” Rogers, 
yang dikutip Perry (dalam Baldwin, 2004:221), mengemukakan pandangannya bahwa "perubahan sosial menyangkut perubahan-perubahan yang terjadi pada struktur dan fungsi sistem sosial." Perubahan tersebut ditandai dengan proses yang di dalamnya terdapat tahap, yaitu: penemuan baru, penyebarluasan penemuan baru, dan penyebaran penemuan baru itu berdampak kepada masyarakat.

Memerhatikan proses ketiga tahapan tersebut, komunikasi memiliki peran pada tahap kedua, yaitu penyebarluasan penemuan baru (inovasi). Teori untuk menelaah bentuk komunikasi tersebut, antara lain, teori difusi inovasi. Teori difusi inovasi, menurut Rogers yang dikutip Perry, adalah "tahap-tahap untuk menyebarluaskan temuan-temuan baru, menyangkut suatu teknologi baru, gagasan baru, ke seluruh anggota masyarakat" ( dalam Baldwin, 2004:221).

Tahap penyebarluasan inovasi dipandang sebagai salah satu tahap penting berkaitan dengan perubahan sosial, karena tidak setiap penemuan baru/inovasi akan begitu saja diterima masyarakat. Peran komunikasi dalam perubahan sosial, seperti dijelaskan Rogers, yang dikutip Perry, "komunikasi itu merupakan elemen yang penting dalam setiap perubahan sosial, meliputi inovasi atau penemuan baru, pengomunikasian melalui berbagai saluran, dalam suatu rentang waktu, dan di antara anggota sistem sosial" (dalam Baldwin, 2004:221). Penjelasan pendapat Rogers tersebut satu per satu diuraikan berikut ini.

Inovasi adalah ide, atau objek yang dipersepsi seseorang sebagai ide baru. Mungkin saja hal itu tidak benar-benar baru, akan tetapi hal itu dirasakan baru oleh orang yang memersepsinya. Menurut Rogers, ide atau gagasan yang menyebar ke masyarakat, pada mulanya adalah berupa inovasi. Oleh sebab itu, dapat terjadi suatu gagasan dipandang baru oleh sekelompok orang, tetapi mungkin sudah biasa bagi kelompok lainnya.

Inovasi mempunyai komponen ide, tetapi sebagian daripadanya tidak memiliki wujud fisik, seperti gagasan baru yang berwujud pemikiran atau ideologi. Inovasi hanya mempunyai komponen ide saja, tanpa wujud fisik, tidak dapat diadopsi secara fisik, pengadopsiannya dilakukan secara simbolik.
Sebaliknya, inovasi yang memiliki komponen ide maupun wujud fisik, pengadopsiannya diikuti oleh keputusan tindakan.

Selanjutnya, Rogers yang dikutip Perry (dalam Baldwin, et al.,2004:222), mengungkapkan, hal yang penting untuk diperhatikan dalam komponen inovasi adalah "setiap inovasi memiliki sejumlah karakteristik yang akan dipersepsi oleh orang yang akan menerima atau menolaknya. Karakteristik itu, antara lain, mencakup: relative advantage, compatibility, complexity, trialability, dan observability."

Relative advantage adalah karakter yang berkenaan dengan apakah suatu inovasi dipersepsi lebih menguntungkan oleh calon pengadopsi jika dibandingkan dengan ide atau cara-cara yang sudah ada yang akan digantikannya. Keuntungan relatif ini diukur dari segi ekonomi, penghargaan sosial, kenyamanan, dan sebagainya.

Karakter compatibility inovasi baru berkaitan dengan kesesuaian inovasi baru tersebut dengan nilai-nilai, pengalaman, dan kebutuhan calon pengadopsi. Inovasi yang tidak sesuai dengan norma yang ada dan dipelihara oleh sistem sosial, tidak akan diadopsi secepat inovasi yang sesuai dengan norma-norma. Complexity adalah karakter inovasi yang berhubungan dengan sejauhmana sebuah inovasi dianggap sulit untuk dipahami oleh calon pengadopsi.

Karakter inovasi trialability berhubungan dengan sebuah inovasi menjadi tinggi tingkat adopsinya jika inovasi tersebut mudah dicoba dalam skala kecil. Sebuah gagasan baru akan menarik calon pengadopsi jika dia dapat mencoba lebih dahulu inovasi itu dalam jumlah tertentu. Terakhir, karakter observability memungkinkan orang yang akan mengadopsi melihat bagaimana dampaknya. Karakter ini membuat sebuah inovasi dapat menyebar dengan cepat di tengah masyarakat.

Terdapat dua saluran yang memiliki peran penting dalam difusi inovasi, yaitu media massa dan saluran antarpribadi. Media massa memiliki peran dalam menyebarluaskan gagasan baru, terutama untuk menjangkau khalayak luas. 
Penggunaan media massa biasanya digunakan, terutama, dalam menumbuhkan pengertian mengenai gagasan baru yang baru disebarkan.

Saluran antarpribadi dalam proses difusi inovasi digunakan pada tahap persuasi, yaitu tahap meyakinkan para calon pengadopsi untuk menggunakan inovasi baru yang diperkenalkan. Penggunaan berbagai saluran komunikasi ini mendorong lahirnya teori tentang arus informasi dari sumber kepada penerima. Mula-mula dijelaskan bahwa pesan-pesan media massa diterima langsung oleh khalayak. Akan tetapi, berbagai penelitian menunjukkan bahwa pesan-pesan media massa seringkali melalui individu-individu tertentu di masyarakat (mereka dikenal dengan opinion leader) kemudian disampaikan kembali kepada khalayak.

Oleh sebab itu, teori difusi menjelaskan bahwa media massa cocok untuk menyebarkan informasi dengan tujuan menumbuhkan pengetahuan dan pengertian. Adapun tindak lanjut dari informasi itu, terutama dalam meyakinkan orang agar mau mengadopsi suatu inovasi lebih dibebankan kepada individu-individu seperti opinion leader atau agen perubahan yang menggunakan saluran antarpribadi.

Waktu merupakan salah satu faktor penting yang harus diperhitungkan dalam proses difusi inovasi. Faktor waktu ini mencakup beberapa konsep difusi, yaitu: proses keputusan inovasi, keinovatifan, dan tingkat adopsi inovasi dalam satu sistem sosial.

Proses keputusan inovasi, yaitu proses perjalanan seseorang sejak mengenal inovasi sampai dia membuat keputusan untuk menerima atau menolak sebuah inovasi melalui empat tahap keputusan, yaitu: pengetahuan, persuasi, keputusan, dan konfirmasi. Tahap pengetahuan adalah tahap ketika seorang calon pengadopsi mulai mengenal inovasi, kemudian dia memahami bagaimana inovasi berfungsi. Tahap persuasi terjadi ketika individu membentuk sikap yang berkenaan atau tidak berkenan terhadap inovasi.

Tahap keputusan terjadi ketika individu melakukan kegiatan yang mengarahkannya kepada satu pilihan untuk menerima atau menolak inovasi. Sedangkan tahap konfirmasi adalah tahap ketika individu mencari penguatan untuk keputusan inovasi yang telah dibuatnya. Dapat saja terjadi individu membatalkan keputusan inovasinya bila dia menemukan informasi yang bertentangan mengenai inovasi yang telah diputuskannya.

Tahap-tahap pengambil putusan ini diambil dalam satu tahap tertentu yang memerlukan waktu. Dari berbagai laporan penelitian, tampak bahwa suatu inovasi tidak dapat diadopsi begitu saja, sebelum orang mempertimbangkannya dalam waktu yang cukup lama.

Faktor waktu dalam adopsi inovasi berkaitan pula dengan tingkat keinovatifan calon pengadopsi. Menurut Rogers, yang dikutip Perry (dalam Baldwin et al., 2004:222), "keinovatifan berkenaan dengan sejauhmana seseorang mengadopsi inovasi lebih dahulu dibandingkan dengan orang lain di masyarakatnya.”

Keinovatifan menghasilkan kategori pengadopsi, di antaranya: innovators, early adopters, late adopters atau laggard. Innovators adalah "orang yang memiliki tiga motivasi dasar-ide, pencapaian, dan ekspresi diri. Mereka mau menerima ide dan teknologi baru, serta pencari tantangan"(Borchers, 2005:146). Early Adopters memperlihatkan "bagaimana teknologi baru bekerja. Bila teknologi tersebut memenuhi janjinya, mereka mengadopsinya, dan bertindak sebagai opinion leader yang mempromosikan inovasi baru kepada orang lain." Sedangkan late adopters atau laggard adalah "mereka yang lambat mengadopsi inovasi baru” (Perry dalam Baldwin et al., 2004:222).

\section{Pola Makan dan Gaya Hidup}

Pada bagian ini dijelaskan secara singkat pola makan dan gaya hidup, food combining (kombinasi makanan serasi), dan siklus sistem pencernaan. Kemudian, dibahas konsep-konsep yang relevan yang terdapat dalam teori difusi informasi mengenai berbagai aspek yang berkenaan dengan gaya hidup sehat dengan menerapkan food combining tersebut.

Selama ini, pemikiran orang mengenai pola makan umumnya terpusat pada makanan kelompok empat sehat (karbohidrat, protein, sayur, dan buah), 
yang dijabarkan sebagai makanan seimbang dalam satu menu. Salah satu aspek yang menentukan pilihan seseorang atas pola konsumsi makan tersebut adalah gaya hidup.

Menurut Kotler, gaya hidup adalah pola hidup seseorang dalam dunia kehidupan sehari-hari yang dinyatakan dalam kegiatan, minat, dan pendapat yang bersangkutan. Hal ini menunjukkan rupa keseluruhan pola perilaku seseorang dalam kehidupan sehari-hari (Kotler, 1992:189).

Pola makan seperti tersebut di atas sudah lazim diketahui, dan diterapkan keluarga-keluarga dalam mengatur menu makanannya. Hal ini berdasarkan anggapan bahwa "setiap kelompok makanan sama pentingnya, sehingga harus dimakan bersamaan, dan protein merupakan unsur yang menentukan dalam standar ukuran menu sehat. Akibatnya, pola makan menjadi terkonsentrasi pada menu seimbang unsur empat sehatnya, tetapi susunan gizinya tidak seimbang dengan kebutuhan tubuh" (Gunawan, 2001:20).

Konsep empat sehat dalam satu menu sebetulnya tidak terlalu menimbulkan masalah seperti sekarang, karena pola makan manusia beberapa puluh tahun yang lalu lebih alamiah. Seperti diungkapkan Gunawan (2001:21), "taraf hidup masyarakat yang meningkat, disertai dengan modernisasi teknologi industri makanan, menyebabkan masyarakat semakin jauh dari makanan-makanan alami. Selain itu, pola makan masyarakat modern sudah dipengaruhi promosi gencar produk-produk makanan tinggi lemak, garam, dan gula. Misalnya, produk sereal bersalut gula, makanan instan, sari buah, margarin, camilan asin, daging olahan, dan sebagainya. Makananmakanan seperti ini tidak memberi kontribusi gizi pada tubuh kecuali tambahan beban dan berat badan."

Selanjutnya, Gunawan (2001:20-21) mengungkapkan hasil pengamatannya mengenai pola makan orang masa kini yang cenderung tidak seimbang, bahkan berlebihan kandungan gizinya. "Pola makan orang sekarang tinggi lemak jenuh dan hidrat arang olahan, tetapi rendah hidrat arang utuh dan lemak tak jenuh ganda. Sebagai contoh, sumber hidrat arang yang lebih banyak dikonsumsi adalah nasi putih dan gula pasir, produk tepung seperti roti dan kue, yang kualitas gizinya rendah akibat proses pengolahan yang lama. Sedangkan hidrat arang yang kualitas gizinya masih utuh seperti kentang, beras merah, atau jagung, umumnya dijadikan makanan selingan atau hampir tidak digemari. Buah atau sayuran yang juga termasuk sumber hidrat arang utuh, lebih sering ditempatkan sebagai makanan sampingan, yang sering malah tidak sempat dimakan karena perut sudah terlalu kenyang. Sebaliknya, asupan protein yang hanya dianjurkan separuh dari total asupan hidrat arang justru sering dikonsumsi lebih dari takaran."

Dengan pola makan seperti itu, yang diperoleh bukannya sehat, melainkan kegemukan dan masalah kesehatan lainnya. Mengenai kelebihan berat badan, banyak faktor yang dapat menyebabkannya. Haas (1992, dalam Gunawan, 2001:18) menyatakan, "faktor keluarga, fisiologis, atau psikologis, bisa melatarbelakangi masalah berat badan. Kebanyakan kasus kegemukan lebih banyak dipengaruhi faktor keluarga daripada kecenderungan genetik."

Faktor fisiologis adalah faktor yang berkaitan dengan kondisi fisik. Misalnya, naiknya berat badan pada masa pertumbuhan anak, wanita hamil, dan pada orang dewasa serta lanjut usia karena kurang olah raga atau gaya hidup yang kurang aktif. Sedangkan faktor psikologis berkaitan dengan kondisi mental atau emosi seseorang. Misalnya, "jika sedang stres, orang cenderung melampiaskan perasaannya dengan makan terusmenerus" (Wirakusumah, 1997:18). Adapun faktor genetik, pencetusnya dihasilkan oleh "gaya hidup yang ditanamkan sejak dini dalam lingkungan keluarga. Jika orang tua yang kegemukan membiasakan pola makan yang buruk dalam keluarga, anak tentu meneruskan kebiasaan pola makan tersebut" (Gunawan, 2001:18).

\section{"Food combining"}

Food combining (kombinasi makanan serasi), menurut Gunawan (2001:34), adalah "metode pengaturan asupan makanan yang diselaraskan 
dengan mekanisme alamiah tubuh, khususnya yang berhubungan dengan sistem pencernaan. Manfaat pola makan ini akan meminimalkan jumlah penumpukan sisa makanan dan metabolisme, sehingga fungsi pencernaan dan penyerapan zat makanan menjadi lancar, dan pemakaian energi tubuh juga lebih efisien."

Banyak tokoh yang mengembangkan program food combining (Gunawan, 2001:36-38). Beberapa, di antaranya, Dokter William Howard Hay, ahli bedah terkenal Amerika tahun 1900-an, telah melakukan penelitian pola makan ini. Ia mengembangkan suatu program pola makan untuk kesehatan yang disebut food separation (pemisahan makanan) atau hay system diet. Dalam perkembangan selanjutnya, pola makan ini dikenal dengan food combining (Gunawan, 2001:36).

Dr. Herbert M. Shelton (1895 - 1985), naturopath, ahli gizi, pengajar dan sekaligus pendiri Dr. Shelton's Health School, di San Antonio, Texas. Ia juga peneliti dan tokoh kesehatan alamiah yang sangat gigih menentang arus pada zamannya. Hasil penelitiannya mengenai food combining dan puasa banyak digunakan oleh ahli-ahli gizi sebagai sumber kepustakaan.

Dr. Norman W. Walker, D. Sc., dikenal sebagai penulis buku-buku masalah kesehatan dan gizi. Selama 70 tahun, tidak pernah berhenti melakukan penelitian mengenai kemampuan manusia berumur panjang dan tetap sehat. Ia sendiri adalah contoh penganut food combining yang mampu mencapai usia 109 tahun dan terbukti tetap produktif sampai akhir hayatnya.

Jan Dries, ahli gizi di negeri Belanda. Selama hampir 20 tahun, ia melakukan penelitian pada ribuan pasien untuk mendapatkan pola diet yang paling tepat bagi setiap penyakit. Lebih dari 600 orang penderita kanker berhasil disembuhkan dengan dries cancer diet, yang merupakan modifikasi metode food combining.

Harvey dan Marilyn Diamond dari Amerika, sepasang suami istri, penulis buku terkenal Fit for Life. Isi bukunya mengungkapkan pengalaman pribadi mereka ketika mengalami kegemukan dan menderita sakit perut akut selama bertahun-tahun yang membuat mereka ketergantungan pada obat penahan sakit. Penyakit Harvey dan Marilyn sembuh dalam waktu singkat setelah mengikuti pola makan food combining. Dalam satu bulan, Harvey berhasil mengurangi $25 \mathrm{~kg}$ kelebihan berat badannya, sedangkan Marilyn $10 \mathrm{~kg}$ dalam enam minggu.

Meski terdapat bukti yang mendukung, namun sebagian besar ahli medis dan gizi tidak seluruhnya sependapat. Mereka yang menentang pola makan ini mengatakan, pencernaan manusia mampu mencerna semua makanan sekaligus, sehingga metode memisah-misahkan makanan tertentu seperti pola makan ini dianggap sebagai perilaku yang tidak masuk akal. Sebenarnya, para pelaku food combining dalam sehari makan sesuai anjuran ahli gizi konvensional empat sehat (karbohidrat, protein hewani, sayur, dan buah). Perbedaaannya, pada pola makan konvensional, menu makan empat sehat di makan bersamaan pada setiap kali makan, sedangkan pada food combining makanan disantap diserasikan dengan siklus tubuh manusia, dan jenis makanan yang dimakan pun bukan pada saat setiap kali makan, melainkan dalam satu hari makan. Contoh menu acuan gizi konvensional dibandingkan dengan food combining dalam sehari dijelaskan pada Tabel 1 .

Memperhatikan uraian pada tabel 1 , pola makan food combining, "melakukan penajaman konstruksi pola makan harian, agar proses pencernaan makanan dan penyerapan sari makanan lebih efektif dan efisien." Pendapat ini diperkuat oleh pernyataan Gunawan, (2001:35), 'berdasarkan siklus alamiah fungsi tubuh manusia, puncak penyerapan dan asimilasi zat gizi terjadi setelah pukul 8 malam sampai pukul 4 pagi, sehingga kurang tepat makanan empat sehat harus dikonsumsi secara bersamaan, karena tiap jenis makanan memiliki perbedaan $\mathrm{pH}$ dan jenis enzim pengurainya. Beberapa unsur gizi memang memerlukan kerjasama dengan unsur lain dalam proses penyerapan. Namun, penelitian ilmiah dalam ilmu gizi juga membuktikan bahwa zat-zat gizi bisa saling melengkapi dalam satu hari makan, bukan dalam satu kali makan." 


\section{Tabel 1}

\section{Contoh Menu Sehari Menurut Acuan Gizi Konvensional} dan "Food Combining"

\begin{tabular}{|l|l|}
\hline \multicolumn{1}{|c|}{ Menu Acuan Gizi Konvensional } & \multicolumn{1}{c|}{ Menu Food combining } \\
\hline Makan Pagi: & Bangun tidur: \\
Nasi & Air putih + sedikit air jeruk nipis \\
Sambal Goreng Kering Daging & Makan pagi (jam 05.30-11.30): \\
Setup bincis dan wortel & Jus semangka \\
Kudapan Pagi: & Apel \\
Bubur Kacang Hijau & Jeruk Manis \\
& \\
Makan Siang: & Makan siang: \\
Nasi & Karedok Sayuran \\
Ikan Goreng & Nasi \\
Sambal Goreng Tahu & Perkedel Kentang \\
Sayur Asam & Tempe Bacem \\
Pepaya & Kudapan sore: \\
Makan Malam: & Lassi Mangga (Mangga + Yogurt) \\
Nasi & Makan Malam: \\
Telur Bumbu Rujak & Salad sayuran \\
Tempe Goreng & Steak daging Sapi \\
Sup Sayuran & \\
Pisang & \\
\hline
\end{tabular}

Sumber: Acuan gizi menurut bagian Gizi RS Dr. Ciptomangunkusumo \& Persatuan Ahli Gizi Indonesia, serta menurut ahli nutrisi Food combining ${ }^{1}$

\section{Siklus Sistem Pencernaan}

Siklus pencernaan, menurut Gunawan (2001:31), "setiap fungsi tubuh mempunyai irama biologis (istilah medisnya circadian rhythm), yang jam kerjanya tetap dan sistematis dalam siklus 24 jam per hari. Jika aktivitas salah satu siklus terhambat, aktivitas siklus berikutnya juga ikut terhambat. Hambatan ini besar pengaruhnya terhadap proses metabolisme." Seperti dijelaskan pada tabel 2.

Tabel 2 menjelaskan metabolisme adalah proses kimiawi yang berlangsung terus-menerus di dalam tubuh, dan sangat penting bagi kelangsungan hidup manusia. Metabolisme erat kaitannya dengan sejumlah aktivitas tubuh yang terjadi di dalam sistem pencernaan-mulai dari proses makan, proses penyerapan, sampai ke proses pembuangan. Melalui metabolisme, juga terjadi proses pembentukan dan pembelahan selsel dari seluruh jaringan tubuh. Ketidakseimbangan metabolisme dapat menimbulkan toksemia (suatu kondisi keracunan di dalam pembuluh darah).

Pada saat kita tidur pun, aktivitas metabolisme tetap berlangsung. Setiap saat di dalam tubuh terjadi pergantian sel, di mana sejumlah 300 sampai 800 miliar sel-sel tua digantikan oleh sel-sel yang baru. Sel-sel tua dan aus tidak diperlukan lagi, sehingga harus segera dikeluarkan melalui seluruh sistem pembuangan seperti dubur, kantung kemih, permukaan kulit, dan paru-paru. Proses ini akan berlangsung secara normal dan alamiah jika keseimbangan metabolisme terjaga. Masalah baru timbul jika sel-sel tua tidak dapat dikeluarkan pada 


\section{Tabel 2}

\section{Siklus Sistem Pencernaan}

\begin{tabular}{|c|c|l|}
\hline No & Siklus & \multicolumn{1}{c|}{ Uraian } \\
\hline \hline 1. & $\begin{array}{c}\text { Siklus Pencernaan } \\
(12 \text { siang }-8 \text { malam })\end{array}$ & $\begin{array}{l}\text { Merupakan saat yang tepat untuk mengonsumsi makanan padat } \\
\text { karena siklus pencernaan bekerja lebih aktif. Setelah pukul 8-9 } \\
\text { malam sebaiknya tidak makan makanan padat lagi karena lambung } \\
\text { tidak boleh sesak dengan makanan pada saat tidur. }\end{array}$ \\
\hline 2. & $\begin{array}{c}\text { Siklus Penyerapan } \\
(8 \text { malam -4 pagi) }\end{array}$ & $\begin{array}{l}\text { Pada saat tubuh dan pikiran kita sedang istirahat total atau tidur, } \\
\text { tubuh mulai menyerap, mengasimilasi, dan mengedarkan zat } \\
\text { makanan. Kurang tidur malam hari atau makan larut malam akan } \\
\text { memboroskan energi dan mengganggu aktivitas siklus ini. }\end{array}$ \\
\hline 3 & $\begin{array}{c}\text { Siklus Pembuangan } \\
\text { (4 pagi - 12 siang) }\end{array}$ & $\begin{array}{l}\text { Secara intensif tubuh mulai melakukan pembuangan sisa makanan } \\
\text { dan sisa metabolisme. Siklus ini paling banyak memakai energi. } \\
\text { Selagi siklus ini berlangsung sebaiknya tidak mengkonsumsi } \\
\text { makanan berat dan padat karena menurunkan intensitas proses } \\
\text { pembuangan, memperlambat proses pencernaan, dan memboroskan } \\
\text { energi. }\end{array}$ \\
\hline
\end{tabular}

Sumber: Gunawan (2001:31)

kecepatan yang sama dengan munculnya produksi sel-sel baru.

Keseimbangan metabolisme juga erat kaitannya dengan efisiensi pemakaian energi. Semakin boros energi yang dipakai, proses pembentukan dan pembelahan sel akan semakin sering dan cepat. Energi tubuh harus dimanfaatkan secara proporsional oleh seluruh fungsi tubuh. Pengurasan energi secara berlebihan dapat menurunkan vitalitas, menyebabkan kulit kusam, lesu kronis, dan penuaan dini (Gunawan, 2001:30$31)$.

\section{Pembahasan}

Pembahasan penyebaran informasi gaya hidup sehat dengan menerapkan food combining ditinjau dari teori difusi inovasi didasarkan pada pola pengaturan asupan makanan yang dipandang sebagai satu inovasi baru ketika disebarkan kepada masyarakat dapat diterima atau ditolak. Dalam menganalisis penyebaran informasi tersebut dipusatkan pada tiga aspek, yaitu karakteristik inovasi, saluran komunikasi, dan rentang waktu adopsi.

\section{“Food Combining” sebagai Inovasi}

Food combining sebagai inovasi di bidang gizi (kesehatan) memiliki wujud sebagai gagasan yang harus disebarkan kepada masyarakat. Sehubungan dengan manfaat besar yang dapat diperoleh masyarakat, antara lain, untuk mencapai derajat kesehatan yang memuaskan. Sebuah inovasi mempunyai karakter tertentu akan dipersepsi oleh calon pengadopsinya. Karakter inovasi dianalisis berdasarkan pada tiga aspek, yaitu: relative advantage (keuntungan relatif), compatibility (kesesuaian), dan complexity (kompleksitas).

Pada karakter keuntungan relatif, berkenaan dengan apa yang dapat ditawarkan ahli food combining kepada masyarakat, jika dibandingkan dengan keuntungan yang disampaikan oleh ahli 
di bidang gizi konvensional, dipandang pada sisi ekonomi. Sebagai inovasi baru, food combining menawarkan keuntungan yang bersifat ekonomis, karena kelebihan menu food combining adalah tingginya sumbangan gizi antioksidan, khususnya betakaroten dan vitamin C. Banyak mengonsumsi buah dan sayuran menjadikan berlimpah senyawa fitokimiawi berkhasiat. ${ }^{8}$ Dengan demikian, menerapkan food combining sebagai gaya hidup sehat memungkinkan orang memiliki peluang besar untuk menikmati hidup, tubuh menjadi sehat, berenergi, terbebas dari penyakit, sehingga menghemat biaya untuk perawatan dari sakit. Karena itu, food combining memberi peluang untuk memeroleh keuntungan ekonomis.

Pada sisi compatibility, kesesuaian food combining dengan nilai-nilai yang ada. Penyebaran informasi food combining memiliki kemungkinan mendapat kesulitan, terutama berhubungan dengan nilai-nilai atau norma yang dianut oleh masyarakat calon pengadopsi. Sebagaimana telah diketahui selama ini pola makan pada umumnya masyarakat mengikuti pola empat sehat (karbohidrat, protein hewani, sayur, dan buah) pada setiap kali makan, bukan pada satu hari makan.

Selain itu, agak sulit mengubah selera makan masyarakat yang sudah sekian lama terbentuk. Sehubungan pola makan food combining mengajarkan sumber karbohidrat tidak dianjurkan disantap bersama sumber protein, khususnya protein hewani. Dengan demikian, menu diatur sebagai kombinasi protein dengan sayuran dan karbohidrat dengan sayuran. Rekonstruksi pola makan food combining memungkinkan setiap zat gizi penghasil energi berada dalam lingkungan paling kondusif untuk menjalani proses pencernaan dan penyerapan. Kalau hal itu dilanggar, bukan hanya proses pencernaan awal karbohidrat yang terganggu, namun tumpukan residu yang ditimbulkannya ikut pula meminimalkan jumlah sari makanan yang dapat diserap tubuh.

Kesulitan lain, adalah mengubah pola asupan makanan ketika sarapan, misalnya, pada umumnya masyarakat terbiasa dengan ajaran hidangan sarapan yang sarat energi, seperti nasi dan sejenisnya, plus pelengkapnya. Hal ini "mengikuti anjuran ahli gizi konvensional untuk menyantap hidangan lengkap, karena pada pagi hari kita bersiap untuk melakukan pekerjaan berat. Padahal, menurut pola food combining, sarapan pagi bukan hidangan komplit yang berat, melainkan buahbuahan segar, kecuali buah sarat lemak seperti alpukat dan durian. Karena pada buah-buahan mengandung zat tenaga sebagai sumber energi."9

Sedangkan pada sisi complexity, food combining sebagai inovasi baru juga memiliki tingkat kompleksitas yang tinggi dan memerlukan pemahaman yang mendalam untuk menerapkan pola kombinasi makanan serasi dalam kehidupan sehari-hari. Jika diamati lebih jauh, seperti dilaporkan dalam artikel di media cetak, umpamanya Kompas, dan majalah Nirmala, pada umumnya mereka yang mencoba menerapkan pola makan ini terbatas pada lingkungan tertentu (perkotaan), dan memiliki perhatian terhadap kesehatan dan kebugaran tubuh. Tetapi, adakalanya mempunyai masalah dengan kesehatannya. Sebagai testimoni, "seorang ibu yang berprofesi sebagai dosen arsitektur di universitas swasta di Bandung, "setelah mengikuti food combining selama 6 bulan, berat badannya turun $16 \mathrm{~kg}$ dari $65 \mathrm{~kg}$, kini berat badannya stabil $(49 \mathrm{Kg})$ dan sembuh dari penyakit hepatitis. ${ }^{10}$ Ada lagi yang lain, "setelah menerapkan food combining trigliseridanya, yang tadinya melambung di atas 400 , menjadi normal kembali."

Banyak di antara mereka yang merasa terbantu dengan menerapkan pola makan ini, khususnya dalam mencapai kesehatan yang maksimal. Sedangkan untuk pengetahuan pola kombinasi makanan serasi yang dimiliki masyarakat pada umumnya, tampaknya belum banyak yang mengetahuinya.

\section{Saluran Komunikasi}

Untuk membahas saluran komunikasi yang digunakan dalam penyebaran informasi food combining, difokuskan pada komunikasi antarpribadi, komunikasi kelompok, dan komunikasi massa. Sesuai dengan hasil penelitian difusi inovasi, 
"penggunaan saluran tersebut efektif dalam penyebaran informasi kepada masyarakat" (Perry dalam Baldwin, 2004:221).

Para ahli nutrisi food combining rupanya menggunakan paduan antara, komunikasi antarpribadi, komunikasi kelompok, dan komunikasi massa dalam menyebarkan informasi kombinasi pola makanan serasi kepada khalayak. Komunikasi antarpribadi adalah "komunikasi antara dua orang yang membangun hubungan" (DeVito, 2001:4). Komunikasi kelompok menunjuk pada " sekumpulan orang yang masing-masing dihubungkan oleh tujuan yang sama dan mempunyai derajat organisasi tertentu di antara mereka" (DeVito, 1997:303). Sedangkan komunikasi massa memusatkan perhatian pada "lima variabel yang terkandung dalam tindak komunikasi, dan memperlihatkan bagaimana variabel tersebut bekerja pada media massa. Variabel tersebut yaitu: sumber, khalayak, pesan, proses, dan konteks" (DeVito, 1997:505).

Merujuk pada pendapat tersebut, konsultasi peserta seminar dengan ahli food combining, masuk dalam bentuk komunikasi antarpribadi. Penyebaran informasinya yang diselenggarakan dalam bentuk seminar, merupakan bentuk komunikasi kelompok. Sedangkan liputan kegiatan tersebut dimuat dalam artikel di media cetak, surat kabar dan majalah, merupakan bentuk komunikasi massa. Hal ini terbukti dengan liputan di berbagai media cetak mengenai pola makan food combining ini. Misalnya, pada seminar-seminar food combining yang diselenggarakan mendapat sambutan hangat. Banyak di antara peserta yang meminta konsultasi lebih jauh mengenai pola makan serasi untuk mereka terapkan dalam kehidupan seharihari. Sebagai contoh, "salah seorang ibu rumah tangga yang berprofesi sebagai wiraswasta mencoba menerapkan food combining untuk keluarganya, setelah membaca sebuah artikel Ny. Andang Gunawan di sebuah majalah. Hasilnya, dia merasakan adanya perbaikan-perbaikan dalam tubuh, kualitas kesehatan keluarga semakin baik dan jauh dari obat-obatan". ${ }^{2}$ Majalah Nirmala membahas laporan khusus "topik food combining, dan seberapa jauh manfaatnya bagi pembacanya. Di samping itu, juga melaporkan tanggapan peserta dalam setiap seminar food combining, mereka yang datang untuk berkonsultasi, bahkan permintaan untuk ceramah food combining semakin meluas ke berbagai kota di Indonesia." 13

\section{Rentang Waktu}

Dalam membahas penyebaran informasi baru, salah satu aspek penting yang perlu diungkap adalah faktor waktu. Hal ini bertujuan agar inovasi dapat menyebar merata ke semua lapisan masyarakat. Berdasarkan hasil penelitian mengenai ide-ide baru yang diungkapkan Rogers seperti dikutip Perry (dalam Baldwin et al., 2004:23), "pada umumnya memerlukan waktu lama."

Dalam penyebaran informasi pola makan food combining, dari sejak mulai diluncurkan, tahun 2001-yang berarti sekarang sudah 7 tahun lebih, mendapat sambutan yang cukup baik dari para inovator. Pada masa awal, pola makan ini dianggap aneh, tetapi kini sudah mulai menyebar dan sudah mulai dikenal oleh para early adopters, apalagi kini akses terhadap sumber-sumber informasi sudah semakin mudah.

Agar dapat dikenal dan diadopsi sebagai inovasi baru, pola makan food combining mungkin tidak seperti inovasi pada umumnya, karena barangkali ada sebagian orang yang sudah memiliki sikap dan perilaku yang menetap atas pola makan sesuai acuan gizi konvensional, atau bersikap ingin melihat bagaimana bukti nyatanya (late adopters). Dengan demikian, tidak heran bila penyebaran informasi ini perlu waktu yang cukup lama. Karena, seperti kita ketahui, pola makan apa pun tidak bersifat mutlak, masing-masing memiliki keunggulan dan keterbatasan. Menjadi tugas konsultan komunikasi kesehatan membantu masyarakat agar mereka mendapat manfaat kesehatan setinggi mungkin dari pola makan yang dijalankan.

\section{Penutup}

Berdasarkan pemaparan terdahulu, maka dapat dikemukakan kesimpulan sebagai berikut: 
(1) Informasi kombinasi makanan serasi (food combining) sebagai inovasi baru di bidang komunikasi kesehatan, tidak terlepas dari pandangan masyarakat tentang karakteristik yang menjadi ciri pada inovasi baru. Antara lain, berkaitan dengan faktor keuntungan relatif, kompatibilitas, dan kompleksitas. Pada karakter keuntungan relatif, berkenaan dengan apa yang dapat ditawarkan para ahlifood combining kepada masyarakat, dapat dipandang pada sisi ekonomi. Karena, dengan menerapkan food combining sebagai gaya hidup sehat, memungkinkan orang, antara lain memiliki peluang yang besar untuk menikmati hidup karena tubuh menjadi sehat, berenergi, dan terbebas dari penyakit. Pada sisi compatibility, kesesuaian dengan nilai-nilai yang ada, penyebaran informasi food combining memiliki kesulitan, terutama berhubungan dengan nilainilai atau norma yang dianut masyarakat calon pengadopsi. Saat ini, pola makan masyarakat pada umumnya mengikuti pola empat sehat (karbohidrat, protein hewani, sayur, dan buah) pada setiap kali makan, bukan pada satu hari makan. Sedangkan pada sisi complexity, food combining sebagai inovasi baru juga memiliki tingkat kompleksitas yang tinggi, dan memerlukan pemahaman yang mendalam untuk menerapkan pola kombinasi makanan serasi ini dalam kehidupan sehari-hari.

(2) Pada aspek saluran komunikasi, para ahli nutrisi food combining menggunakan paduan antara komunikasi antarpribadi, komunikasi kelompok, dan komunikasi massa dalam menyebarkan informasi kombinasi pola makanan serasi kepada msyarakat.

(3) Dalam penyebaran informasi, pola makan food combining memerlukan waktu yang cukup lama. Karena, sesuai dengan hasil riset, penyebaran ide-ide baru memerlukan waktu yang cukup lama tersebar kepada masyarakat. Agar informasi pola makan food combining dapat dikenal dan diadopsi sebagai inovasi baru, diperlukan upaya yang kuat dari konsultan nutrisi atau komunikasi kesehatan yang mampu membantu masyarakat agar mereka mendapat manfaat kesehatan setinggi mungkin dari pola makan yang dijalankan.

\section{Catatan Akhir}

1 Pikiran Rakyat.2007. "Waktunya Turunkan Berat Badan." Pikiran Rakyat.1 Oktober

2 Nova.2007. "Ingin Sehat Salah Satunya dengan Mengatur Pola Makan.” No. 1034/XX/17-23 Desember 2007.

3 Gunawan, Andang. 2002. "Ulang Tahun sebagai Refleksi." Majalah Nirmala 05/IV/Mei/2002.

4 Piotrow, P.T.; Kincaid, D.L.; Rimon,II,J.G.; et al. Health Communication.Westport, CT: Praeger, 1997. Dalam Health Communication 11.[www.healthypeople.gov/ Document/HTML/Volume1/11 HealthCom.htm] $<25$ / $06 / 2003>$.

5 Jackson,L.D.,and Duffy,B.K.,eds. Health Communication Research.Westport, CT: Greenwood,1998. Dalam Health Communication 11.[www.healthypeople.gov/ Document/HTML/Volume1/11 HealthCom.htm] $<25$ / $06 / 2003>$

6 Apriadji, Wied Harry. "Food Combining, Ilmiah dan Rasional." Majalah Nirmala. 05/IV/Mei 2002, hal. 13.

7 Apriadji, Wied Harry. "Food Combining, Ilmiah dan Rasional.” Majalah Nirmala. 05/IV/Mei 2002, hal. 9.

8 Apriadji, Wied Harry. "Food Combining, Ilmiah dan Rasional.” Majalah Nirmala. 05/IV/Mei 2002, hal. 9.

9 Apriadji, Wied Harry. "Food Combining, Ilmiah dan Rasional." Majalah Nirmala. 05/IV/Mei 2002, hal. 9.

10 Gunawan. 2001. "Pengalaman mengikuti Food Combining," hal. 129.

11 Nirmala. 2002. "Wied Harry Apriadji." Rubrik 'Tamu Kita' majalah Nirmala 05/IV/Mei 2002, hal. 16.

12 Pintasari, Tarita "Surat Anda" Majalah Nirmala, 05/IV Mei 2002, hal.14.

13 Gunawan, Andang. 2002 "Ulang Tahun Sebagai Refleksi.” Majalah Nirmala, 05/IV/Mei 2002, hal.3.

\section{Daftar Pustaka}

Apriadji, Wied Harry. 2002. "Food Combining, Ilmiah dan Rasional.” Majalah Nirmala. 05/ IV/Mei, hal. 9. 
Borchers, Timothy A. 2005. Persuasion in the Media Age. Second Edition. New York: Mc.Graw-Hill.

DeVito, Joseph A. 1997. Komunikasi Antarmanusia. Penerjemah Agus Maulana, Jakarta: Professional Books.

. 2001. The Interpersonal Communication Book. New York: Addison Longman Inc.

Gunawan, Andang. 2001. Food combining: Kombinasi Makanan Serasi, Pola Makan untuk Langsing dan Sehat. Jakarta: PT Gramedia Pustaka Utama.

"Pengalaman mengikuti

Food combining" (Sisipan) Jakarta: PT Gramedia Pustaka Utama.

Jackson,L.D.,and Duffy,B.K.,(eds.) Health Communication Research. Westport, CT: Greenwood,1998. Dalam Health Communication 11. [www. healthypeople. gov/document/HTML/ Volume1/11HealthCom.htm] $<25 / 06 / 2003>$.

Kasali, Rhenald. 1998. Membidik Pasar Indonesia: Segmentasi, Targeting, Positioning. Jakarta: PT Gramedia Pustaka Utama.
Nova. 2007.'Ingin Sehat Salah Satunya dengan Mengatur Pola Makan". No. 1034/XX/17-23 Desember.

Nirmala. 2002. "Wied HarryApriadji”. Rubrik Tamu Kita majalah Nirmala 05/IV/Mei.

Perry, Stephen D. 2004. "Media: A Tool to Meet Our Needs". Dalam Baldwin, John R., Perry,S.D., \& Moffit,M.A. Communication Theories for Everyday Life. Boston: Pearson Education, Inc.

Pikiran Rakyat. 2007. "Waktunya Turunkan Berat Badan." Pikiran Rakyat. (1 Oktober).

Piotrow, P.T.; Kincaid, D.L.; Rimon,II,J.G.; et al. Health Communication. Westport, CT: Praeger, 1997. Dalam Health Communicatio11.[www.healthypeople.gov/ Document/HTML/Volume1/ HealthCom.htm]<25/06/2003>.

Soekamto, Soerjono.1982. Sosiologi Suatu Pengantar. Jakarta: CV. Rajawali.

Wirakusumah, Emma S. 1997. Cara Aman dan Efektif Menurunkan Berat Badan. Jakarta: PT. Gramedia Pustaka Utama. 